\title{
DEVELOPING EMOTION REGULATION SKILLS BY EMOTION REGULATION SKILLS SYSTEM TRAINING FOR CHILDREN WITH MILD INTELLECTUAL DISABILITY
}

\author{
Efika Fiona; Wahyu Indianti \\ Faculty of Psychology, Universitas Indonesia \\ E-mail: efikafiona@gmail.com; wisitorus@gmail.com
}

\begin{abstract}
Intellectual disability is deficits in intellectual functions, adaptive functions, and these deficits occure during the developmental period (before the age of eighteen). Emotion regulation related to the functions and become the problems for children with mild intellectual disability. Emotion regulation is individual's ability to refrain himself from improper behavior concerning negative and positive emotions that he feels, to manage himself so that he does not depend on his mood condition, to calm down himself when strong emotion arises, and to focus his attention when strong emotion appears. Emotion regulation is extremely needed for adaptation in maintaining relations with other people. The one of interventions that can be used to handle emotion regulation problem for children with intellectual disability is by giving emotion regulation skills system training. This research uses single subject design. The result of this research shows that emotion regulation skills system training gives positive impacts on cognitive and behavior aspects of the subject. The application of these skills in daily life is related to the roles of people around the subject who can understand how to apply the skills and remind the subject.
\end{abstract}

Key words: mild intellectual disability, emotion regulation, skills system training

\begin{abstract}
Abstrak
Disabilitas intelektual merupakan kondisi dimana seseorang mengalami keterbatasan pada fungsi kognitif, adaptif, dan adanya keterlambatan pada perkembangan yang terjadi sebelum usia 18 tahun. Salah satu hal yang menyangkut fungsi-fungsi tersebut dan biasanya bermasalah pada penyandang disabilitas intelektual ringan adalah regulasi emosi. Regulasi emosi merupakan kemampuan seseorang untuk menahan diri terhadap perilaku yang tidak sesuai terkait dengan emosi negatif ataupun positif yang dirasakan, mengatur diri supaya tidak tergantung dengan suasana hati, menenangkan diri ketika muncul emosi yang kuat, dan memfokuskan atensi ketika muncul emosi yang kuat. Regulasi emosi sangat dibutuhkan untuk beradaptasi hingga menjaga hubungan dengan orang lain. Intervensi yang dapat digunakan untuk menangani masalah regulasi emosi adalah pemberian pelatihan sistem keterampilan regulasi emosi. Penelitian ini menggunakan desain single subject. Hasil penelitian ini menunjukkan bahwa pelatihan sistem keterampilan regulasi emosi memberikan dampak positif pada aspek kognitif dan perilaku subjek. Penggunaan sistem keterampilan dalam keseharian juga berkaitan dengan peranan orang-orang di sekitar subjek yang memahami cara penggunaan keterampilan dan mengingatkannya pada subjek.
\end{abstract}

Kata kunci: disabilitas intelektual ringan, regulasi emosi, pelatihan sistem keterampilan. 


\section{INTRODUCTION}

Human beings are social beings who interact with each other. In interacting, they often involve their emotions. Emotions that they feel basically need to be expressed, but of course with suitable manner in order that inter human relations can be well maintained. Someone`s ability to identify the emotion that he feels, when he experiences the emotion, and how he expresses the emotion that he feels is called emotion regulation (Gross, 1998b as cited in Gross, 2014). Panfile and Laible (2012) also describe emotion regulation as someone's ability to express his emotion in a controlled way as a response to the stimulus that exists in his surrounding environment. Hence, it can be stated that emotion regulation is someone`s way to express his emotion range properly as a response to the situation that he faces.

Emotion regulation ability is developed from childhood, when children learn to express and experience emotion (Scanlon, 2010) and this ability continues to develop for life (Cole, Dennis, Smith-Simon, \& Cohen, 2009). Emotion regulation development has started from early age. For instance, one-year-old children consciously regulate their emotions. 3-5 year old children (kindergarten age) specifically need to understand other people`s emotion responses as their understanding toward an event may trigger specific emotion response (Mills \& McCarrol, 2012). Emotion regulation mechanism development during children`s first year of age is very important for the development of emotion regulation ability during childhood and further development (Cole et al., 2009). In other words, emotion regulation ability can be formed as early as possible starting from childhood. Factors that play role in emotion regulation are: (1) emotion that is being felt, (2) emotion intensity, and (3) emotion strategy habits being used.

Children having good emotion regulation ability are those capable of expressing their emotion with suitable manner starting from identifying, managing, and responding to emotion that they feel. Children who have good regulation ability are usually favoured by their surrounding social environment, they are better in handling conflicts, and they have better interpersonal ability (Scanlon, 2010).

Different from children having good emotion regulation, children with bad emotion regulation ability are more often sighted showing defiant or aggressive behavior toward surrounding people (Calkins, Smith, Gill, \& Johnson, 1998; Schatz, Smith, Borkowski, Whitman, \& Keogh, 2008). Furthermore, children whose emotion regulation development is not complete usually have problems in forming meaningful relations with other people (Stack, Serbin, Enns, Ruttle, \& Barrieau, 2010). Other research results also show strong negative effects on children who do not achieve the ability to regulate their emotions (Mills \& McCarroll, 2012). The impacts that appear on children with bad emotion regulation development can make their needs as social beings to interact with other people not fulfilled. Such impacts also occur on children with intellectual disability 
and they usually have problems in regulating their emotions. Children with intellectual disability experience deficit in attention ability, memory, language development, selfregulation, and motivation (Hallahan \& Kauffman, 2006).

Children with intellectual disability comprise different seriousness ranging from mild to profound. The more serious the intellectual disability that a child experiences, the more dependent he is on people around him (McClure, Halpern, Wolper, \& Donahue, 2009). Therefore, a child with mild intellectual disability is more capable to be trained and nurtured to manage himself than a child with profound intellectual disability.

In emotion development, children with mild intellectual disability can recognize and identify their own emotion and the emotion of other people (Lindsay, Mitchie, Baty, Smith \& Miller, 1994; Rose \& West, 1999). Moore (2001) reports that a person with intellectual disability can differentiate happy emotion from unhappy emotion like a normal person without intellectual disability. Glenn \& Cunningham (2002) states that a person with intellectual disability has a slower emotion regulation process than that of a person without intellectual disability. The aggressive and problematic behavior level is high among children with intellectual disability (Taylor, 2002). Those behaviors usually stem from failures in regulating anger emotion (Black, Cullen, \& Novaco, 1977). Sovner and Hurley (1986) have also reported that symptom presentations in populations with intellectual disability are affected by limited abilities to interpret internal states, difficulties with expressive and receptive language, limited mental flexibility, and decreased behavioral control and ability to plan ahead. Failure to regulate emotion can also be seen in the behavior of the subject in this research when he is angry with his friend by hitting him repeatedly, pinching him, and pulling his hair.

Based on the research, some interventions succesfully that can increase emotion regulation ability: attention modification, Mindfulness Training (MT), Emotion Regulation Therapy (ERT), Affect Regulation Training (ART), and Dialectical Behavior Therapy (DBT) (Berking \& Schwarz, 2014; Farb, Anderson, Irving, \& Segal, 2014; MacLeod \& Grafton, 2014; Linehan, 2015). Attention modification, MT, and AFT interventions can be done for clients who have sufficient cognitive ability because they can concentrate on the stimulus in the surrounding (Berking \& Schwarz, 2014; Farb, Anderson, Irving, \& Segal, 2014; MacLeod \& Grafton, 2014). By that definition, interventions such as attention modification, MT, and AFT are not suitable for for a subject with intellectual disability. Meanwhile, ERT technique also requires the client to have high cognitive ability to understand self value and change the value (Mennin \& Fresco, 2014). Hence, ERT intervention is not suitable for subjects with intellectual disability because the cognitive capacity is limited. Therefore, DBT approach is suitable for the subject with intellectual disability. DBT is a therapy that focuses on emotion regulation development, using cognitive and behavior strategy, and reducing maladaptive behavior. DBT views emotion regulation as the product of support from biological factors (cognitive capacity) 
and environment (opportunity and feedback obtained in doing emotion regulation) (Lew, Matta, Trip-Tebbo, \& Watts, 2006; Njardvik, Matson, \& Cherry, 1999). It is also in line with biosocial theory. According to biosocial theory as the basis for DBT, biological, environmental, and their interactions play role in someone`s behavior. The standard DBT skills (Linehan, 2015) were not specifically designed for individuals with intellectual disability. The standard DBT skills use the multisyllabic terms, complex mnemonics, abstract language, and modular teaching process. Lack of structure to facilitate integration of the divergent elements create barriers for vulnerable learners (Kalyuga, 2011; Pass \& Sweller, 2012; Sweller, 1988, 2010; van Gog, Paas, \& Sweller, 2010). In line with the researches that have been conducted, there is a development of DBT-informed approach. DBT informed-approach has been developed to increase emotion regulation ability specifically people with intellectual disability by Brown (2016). This DBT-informed version (Emotion Regulation Skills System) may not look like DBT because the understandable words that are used in the training are necessary to enable vulnerable learners to get access to the essence of DBT.

In that skills system it is stated that there are 9 skills that are needed to conduct emotion regulation. They are: (1) Clear picture functions to help focus attention so that the subject realizes his condition and the condition of the surrounding; (2) on-track thinking functions to help produce thinking suitable for achieving the goal; (3) on-track action functions to help determine actions suitable for achieving the goal; (4) safety plans function to help realize the danger risk level being faced and choose actions most suitable to face the situation; (5) new-me activities function to help recognize activities that can help someone to stay on-track for his goal; (6) problem solving functions to determine when and how to solve problems in order to achieve the goal; (7) expressing myself functions to teach how to express what is in mind and the feeling of someone; (8) getting it right functions to teach how to express what someone wants and needs; (9) relationship care functions to manage relationship with oneself and other people in the surrounding. These nine skills are taught to children with intellectual disability to help them in doing emotion regulation in daily life. This emotion regulation skills system training can be conducted to individuals or to groups. Therefore, this research wants to investigate whether the emotion regulation skills system training is effective in developing the emotion regulation ability of children with mild intellectual disability.

\section{METHOD}

\section{Participant}

The characteristics of the participant are a child with mild intellectual disability who has emotion regulation problems which are characterized by hitting, pinching, and hair 
pulling and other actions that disturb other people and hamper the other people activities. This participant is a ten year old male student who has mild intellectual disability ( $\mathrm{QQ}=54$ ) based on Wechsler scale and on the observations and interviews. The participant often overreacts (hitting repeatedly/pinching/hair pulling) friends who touch him first, does not readily accept the warning of other people to him and sometimes blames a friend or cries, and what he wants difficully knowed by other people (for instance, asking someone to unwrap food by just body movement).

\section{Research Design}

The purposes of the research was knowing the effectiveness of emotion regulation skills system training for children with mild intellectual disability. The research design is single subject design which to see the treatment impact on the subject's emotion regulation. The subject behavior was measured several time before treatment as baseline. When treatments was given, the subject emotion regulation is constantly observed. The change of subject's behavior from baseline to treatment was the evidence of the treatment effect (Cozby \& Bates, 2012). The experiment design used in this research was AB design consisting one baseline phase (A) and one treatment phase (B) (Gravetter \& Forzano, 2009). The treatment that was given by the researcher was the emotion regulation skills system training. The effect of the treatment was drawn from the comparison of measurement before treatment (A) and after treatment (B). The efect of the intervention was achieved if: (1) in the cognitive aspect, the participant's score increase from pretest to the posttest and at follow up results with the minimum score of 75 or $3 / 4$ of the range 0 100; (2) in the emotion regulation behavior aspect, the subject's score decreased in the percentage of improper emotion regulation behavior that can be seen from observation result; (3) the subject's score in ERC questionnaire increased; (4) the subject used adaptive emotion regulation skills during follow up period after intervention, at least three of nine skills that have been taught in emotion regulation skills system training that based on the minimum skills system that becomes the first step for a individual to regulate emotion.

\section{Instruments}

This intervention focused on two aspects; cognitive aspect or knowledge of the participant about emotion regulation skills and behavior aspect which refers to the subject's performance on emotion regulation. The researcher used a measurement in the form of problems. The problems are constructed from the questions found in the book Emotion Regulation Skills System (Brown, 2016) with the answer choices for all problems. All the questions represent the nine skills that measured the cognitive aspect that include 20 questions with the multiple choice and short filling-in answer options. For 
each correct answer, the participant gets the score 5, therefore, the minimum score is 0 and the maximum score is 100 .

The emotion regulation behavior aspect was measured by observation checklist procedure based on verbal and physical improper behavior that initially drawn from interview results and then compared by the situation that triggers the behavior appearance. The observation sheets are filled by the classroom teacher and assistant teacher in the classroom before, during, and after intervention. The ratio of the appearance percentage of improper behavior (TAPIB) and the number of situation that trigger the improper behavior are the participant's performance of the emotion regulation skills.

$\operatorname{TAPIB}(\%)=\frac{\text { the number of the appereance of improper behavior }}{\text { the number of situation that trigger the improper bahvavior }} \times 100 \%$

The other measure for behavior aspect was emotion regulation checklist (ERC) questionnaire (Shield and Cicchetti, 1997) that had been developed in Indonesian by Handali (2017). ERC questionnaire is filled by classroom teacher, assistant teacher, the subject's mother and grandmother that consisted 24 Likert Scale type (1=never; $2=$ seldom; $3=$ often; 4=always) items.

\section{Procedure}

This research was conducted in three steps, preparation, implementation, and data analysis. Preparation step included needs analysis, literature study, and the construction of intervention program or moduls for emotion regulation skills system training. Implementation step was conducting the intervention that included measuring the participant's knowledge and behavior of emotion regulation and the introduction to emotion regulation skills system. The learning technique of the intervention was the gradual direct learning that instructing emotion regulation skills system. The learning was supported by various learning tool such as cards as clues about what is being learned, and videos as models and activities of skills. The apperception was always given at beginning of a meeting. The participant get the reward when he succeeded attending full time of the class that serve as reinforcement to engage in all class or meeting. At the implementation, the worksheets was given to the participant to practice the skills that havd been learned. At the last (the sixth) meeting, the knowledge of the participant about emotion regulation skills was measured for two time in one week to see how the particpant maintain and applied it in daily life. 
The intervention had conducted six meeting that consists of two 45-60 minutes sessions. The materials were presented in the main points of every skill that easy for the participant for understanding.

Table 1

Objectives And Activities in Intervention Meetings

\begin{tabular}{|c|c|}
\hline Objectives of Meetings and Sessions & Activities \\
\hline $\begin{array}{l}\text { Meeting } 1 \\
\text { S1: Introducing } 9 \text { skills and functions } \\
\text { S2: Introducing general picture of skills usage }\end{array}$ & $\begin{array}{l}\text { - Interactive discussion } \\
\text { - Playing Skills Cards \& Emotion Cards } \\
\text { - Filling in worksheets }\end{array}$ \\
\hline $\begin{array}{l}\text { Meeting } 2 \\
\text { S1: Introducing and practicing skill } 1 \text { (clear picture) } \\
\text { S2: Introducing and practicing skill } 2 \text { (on-track thinking) }\end{array}$ & $\begin{array}{l}\text { - Viewing video } \\
\text { - Interactive discussion } \\
\text { - Practicing the use of Skills } 1 \text { and } 2 \\
\text { - Filling in worksheets }\end{array}$ \\
\hline $\begin{array}{l}\text { Meeting } 3 \\
\text { S1: Introducing and practicing skill } 3 \text { (on-track action) } \\
\text { S2: Introducing and practicing skill } 4 \text { (safety plan) }\end{array}$ & $\begin{array}{l}\text { - Viewing video } \\
\text { - Interactive discussion } \\
\text { - Practicing the use of skills } 3 \text { and } 4 \\
\text { - Filling in worksheets }\end{array}$ \\
\hline $\begin{array}{l}\text { Meeting } 4 \\
\text { S1: Introducing and practicing skill } 5 \text { (new-me activities) } \\
\text { S2: Introducing and practicing skill } 6 \text { (problem solving) }\end{array}$ & $\begin{array}{l}\text { - Viewing video } \\
\text { - Interactive discussion } \\
\text { - Practicing the use of skills } 5 \text { and } 6 \\
\text { - Filling in worksheets }\end{array}$ \\
\hline $\begin{array}{l}\text { Meeting } 5 \\
\text { S1: Introducing and practicing skill } 7 \text { (expressing myself) } \\
\text { S2: Introducing and practicing skill } 8 \text { (getting it right) }\end{array}$ & $\begin{array}{l}\text { - Viewing video } \\
\text { - Interactive discussion } \\
\text { - Practicing the use of skills } 7 \text { and } 8 \\
\text { - Filling in worksheets }\end{array}$ \\
\hline $\begin{array}{l}\text { Meeting } 6 \\
\text { S1: Introducing and practicing skill } 9 \text { (relationship care) } \\
\text { S2: Introducing and practicing skills system combination }\end{array}$ & $\begin{array}{l}\text { - Viewing video } \\
\text { - Interactive discussion } \\
\text { - Practicing the skill } 9 \text { and skills system combination } \\
\text { - Playing Skills Cards \& Emotion Cards } \\
\text { - Filling in worksheets }\end{array}$ \\
\hline
\end{tabular}

\section{RESULTS}

The results being presented start from baseline, during intervention, and after intervention (follow up). Observation sheets are filled by the classroom teacher and assistant teacher. The following is the result based on the subject behavior observation starting from baseline until follow up period. Figure 1 shows that the percentage of unsuitable behavior for emotion regulation appears $100 \%$ during the baseline period from day 1 to day 5 representing the subject's behavior not suitable for emotion regulation.

During the six intervention meetings, there is a decrease in the percentage of the subject's unsuitable behavior for emotion regulation, but in the fourth meeting there is an increase again. This occurs because the emotion condition of the subject is not good because his family member got angry with him. As a result, his behaviors tend to be disturbing such as it is difficult for people around to remind him, he is not willing to participate in class activities. 


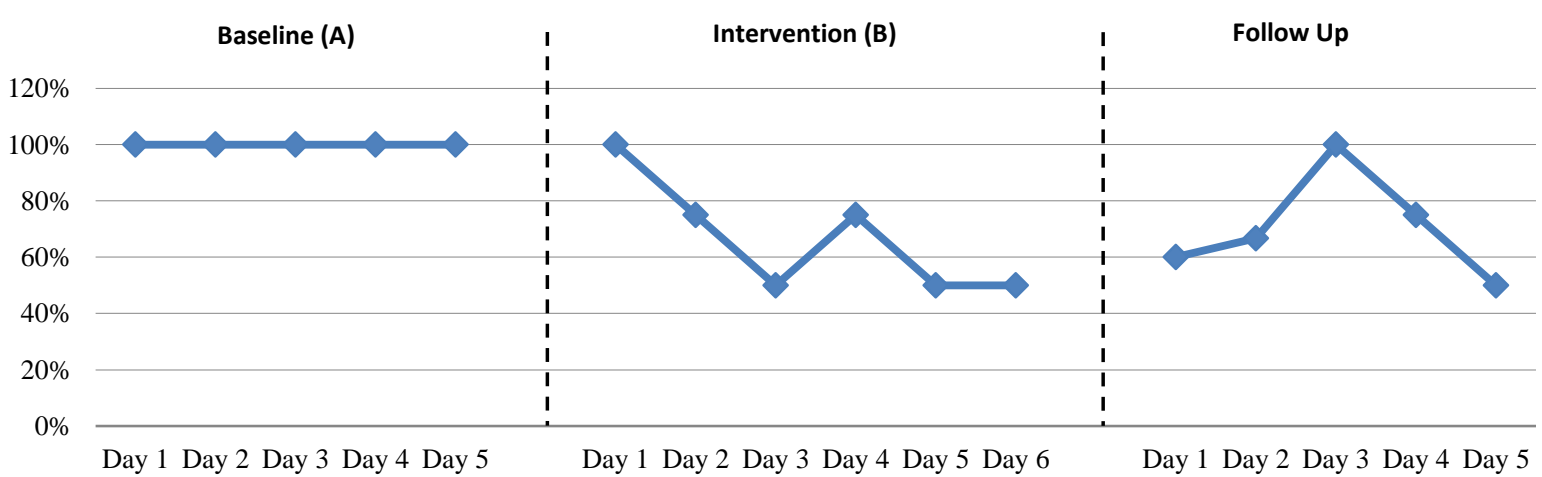

Figure 1. The appearance of improper/unsuitable emotion regulation behavior

During the follow up period, the percentage of unsuitable behavior for emotion regulation decreases. In day 3 follow up period, there is an increase in the percentage of unsuitable behavior for emotion regulation. This is caused by the emotion condition of the subject who is so happy and excited about swimming training that he shows disturbing behaviors such as repeating his own words that it disturbs the learning process in class. In days 4 and 5, the percentage decreases again.

The following is table shows the average percentage of behavior that is not suitable for emotion regulation during baseline and follow up periods.

Table 2

The comparison of observation results at the baseline and follow up periods

\begin{tabular}{lcccccccc}
\hline & \multicolumn{7}{c}{ The appearance percentage of improper behavior } \\
\cline { 2 - 8 } Baseline & Day 1 & Day 2 & Day 3 & Day 4 & Day 5 & Mean & $\mathrm{t}$ & Sig (2-tailed) \\
Follow up & $100 \%$ & $100 \%$ & $100 \%$ & $100 \%$ & $100 \%$ & $100 \%$ & 3.502 & 0.025 \\
\hline
\end{tabular}

Based on the statistical test result, $\mathrm{t}=3,502$; sig $(2$-tailed $)=0.025$. This result shows that $p<0.05$. Therefore, it can be stated that there is a significant decrease in the behavior that is not suitable for emotion regulation. ERC questionnaire is filled by 4 raters. They are the subject's mother, grandmother, classroom teacher, and assistant teacher. 


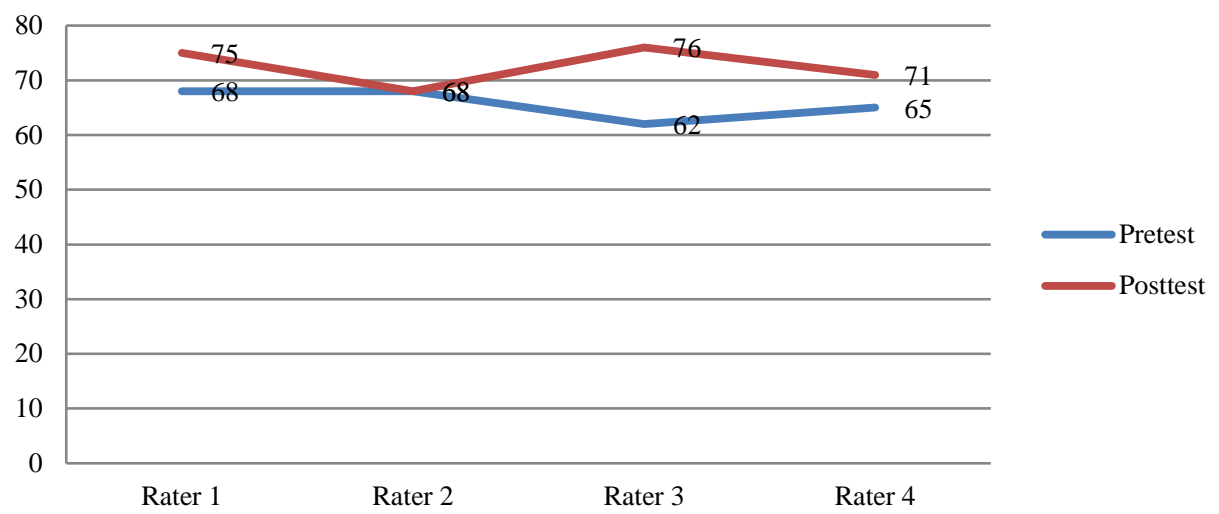

Figure 2. The results of ERC score

Figure 2 shows that there is an increase in ERC score result that is obtained from pretest period to post-test period. Only one rater shows the same score. The other three rater present score increases.

Table 3

The comparison of ERC pre-test and post-test results

\begin{tabular}{lccccccc}
\hline & Rater 1 & Rater 2 & Rater 3 & Rater 4 & Mean & t & Sig. (2-tailed) \\
\hline Pre-test & 68 & 68 & 62 & 65 & 65.75 & 2.353 & 0.100 \\
Post-test & 75 & 68 & 76 & 71 & 72.50 & & \\
\hline
\end{tabular}

Based on the statistical test, $\mathrm{t}=2,353$; sig $(2$-tailed $)=0.100$. This result shows that $\mathrm{p}>0.05$. Therefore, it can be stated that there is a non-significant increase in the ERC score.

The questions are answered by the subject. From the evaluation result of the subject's knowledge scores, the following result is obtained.

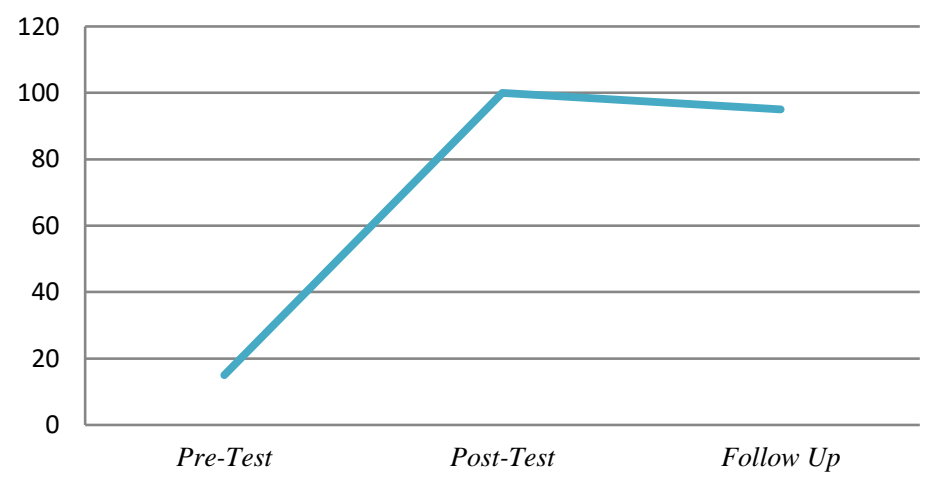

Figure 3. The results of emotion regulation knowledge score 
Figure 3 shows that there is an increase in the knowledge score of the subject which is obtained from the answers given by the subject. In the pretest, the subject obtains score 15. In the post-test, the subject obtains score 100 representing a significant increase. In the follow up period, the subject experiences a little decrease in the score which is becoming 95 .

The evaluation result of the skills application in daily life can be seen on the following behavior comparison table based on the reports from the teacher and the parents.

Table 4

The Comparison of Subject's Behavior Before and After Intervention (Follow Up)

\begin{tabular}{|c|c|c|c|}
\hline The Situation & $\begin{array}{l}\text { The subject behavior before } \\
\text { Intervention }\end{array}$ & $\begin{array}{l}\text { The subject behavior during } \\
\text { Follow up period }\end{array}$ & $\begin{array}{l}\text { Locatio } \mathrm{n} \text { of } \\
\text { behavior change }\end{array}$ \\
\hline $\begin{array}{l}\text { When the subject is } \\
\text { warned and given } \\
\text { explanation }\end{array}$ & $\begin{array}{l}\text { It is difficult for him to accept } \\
\text { and he tends to evade }\end{array}$ & $\begin{array}{l}\text { He accepts and does not evade } \\
\text { (on-track thinking and } \\
\text { on-track action skills) }\end{array}$ & School \\
\hline $\begin{array}{l}\text { When the subject is } \\
\text { first disturbed by his } \\
\text { friend }\end{array}$ & $\begin{array}{l}\text { Overreacts to what his friend } \\
\text { has done. For instance, when } \\
\text { his friend touches him one } \\
\text { time, he will hit/tuft/pinch } \\
\text { his friend more than five } \\
\text { times. }\end{array}$ & $\begin{array}{l}\text { He still reacts, but not overreacts. } \\
\text { He ever does not respond to his } \\
\text { friend's disturbance, but he reports } \\
\text { to the teacher (problem solving } \\
\text { and expressing myself skills) }\end{array}$ & School \\
\hline $\begin{array}{l}\text { When the subject } \\
\text { wants to ask for help } \\
\text { and after being helped }\end{array}$ & $\begin{array}{l}\text { He usually does not speak } \\
\text { clearly and nobody knows } \\
\text { what he wants and then } \\
\text { after that, he does not thank. }\end{array}$ & $\begin{array}{l}\text { He has expressed it clearly } \\
\text { using the word "help" and expresses } \\
\text { "thanks" after being helped. } \\
\text { (getting it right skill) }\end{array}$ & School and home \\
\hline $\begin{array}{l}\text { When the subject } \\
\text { wants to go to the } \\
\text { toilet }\end{array}$ & $\begin{array}{l}\text { He usually just goes away } \\
\text { without getting permission from } \\
\text { the teacher }\end{array}$ & $\begin{array}{l}\text { He asks for permission to the } \\
\text { teacher first and expresses thank } \\
\text { after given permission } \\
\text { (getting it right skill) }\end{array}$ & School \\
\hline $\begin{array}{l}\text { When the subject is } \\
\text { tired to do his home } \\
\text { work }\end{array}$ & $\begin{array}{l}\text { He usually weeps, but he has } \\
\text { been able to express that he is } \\
\text { tired }\end{array}$ & $\begin{array}{l}\text { He still wants to cry, but he has } \\
\text { started to say that he is tired } \\
\text { (expressing myself skill) }\end{array}$ & Home \\
\hline
\end{tabular}

Table 4 shows that the subject has applied more than three skills that have been taught in the emotion regulation skills system training. But the behavior change is clearer in school than at home. This is explained further in the discussion section.

\section{DISCUSSION}

This research is aimed at finding out the effectiveness of emotion regulation skills system training in developing emotion regulation skills for children with mild intellectual disability. The emotion regulation skills system is chosen as the treatment in this research because it is constructed to maximize learning, integration, and ultimately generalization of the skills into life contexts. This skills system is also user friendly for individuals with learning disabilities because it is simpler to apply in life contexts (Brown, 2016). 
The subject of this research is a ten- year-old male student with mild intellectual disability. Baseline result shows the appearance of behavior not suitable for emotion regulation (100\% appearance). This shows that the subject tends to show behavior which is not suitable when facing situations that trigger his emotion response appearance. The situations are as follows: when a friend touches him, when he is given a warning, and when he cannot get what he wants. The behavior that appears, for instance, is hitting/pinching/tufting a friend too much, crying/evading/blaming other friends when given a warning, crying/not accepting when his will is not fulfilled, not expressing clearly what he wants (for instance, when he needs help or permission), and repeating words when he feels happy that is disturbing to other people.

In line with the teaching of skills obtained by the subject concerning emotion regulation, the subject begins to show reduction of behavior that is not suitable for emotion regulation. The first three skills (clear picture, on-track thinking, on-track action) being taught are intended to make him aware of his own self and the surroundings, what he has in mind, and his actions. With those skills, the subject can realize his emotion condition and the situation that he faces. The other skills are used to help the subject in various situation of life. As stated by Linehan (2015), in dialectical therapy approach, the focus of attention for the subject is how to realize and accept the situation and condition that he faces. In the 6 intervention meetings, the subject tries to practice this clear picture skill especially the breathing exercise. The subject does the breathing exercise without being instructed by the researcher, namely when he seems to feel tired, he still wants to complete the worksheet that he is doing.

The observation result also shows a decrease in the behavior that is not suitable for emotion regulation. But on the fourth day of the intervention period something happened in the house of the subject that made him upset before going to school. He became cranky that day including during the intervention. But the next day the unsuitable bahavior decreased again. Besides that, on the third day of the follow up period, the subject shows again a behavior that is not suitable for emotion regulation, namely repeating words because he feels very happy when he is informed that he is included in the swimming competition and that he will be given swimming training by his teacher. This is also felt by the teacher to be quite disturbing since the subject is very enthusiastic. But on the next days, the unsuitable behavior decreases again. The increase in the unsuitable behavior on the third day during the intervension period and on the fourth day during the follow up period may be caused by the fact that the subject is still influenced by the emotion intensity being felt before. This is in line with the research result stating that when emotional intensity is high, the perseverative focus or rumination (the thinking about bad events in the past) is boosted and the behavior becomes maladaptive (Nolen-Hoeksema, 1991). It is understandable that the emotion with stronger intensity tends to be more difficult to be regulated. Besides that, the emotion regulation process consists of some 
stages starting from before emotion appears until after it appears. The later stage of the emotion regulation becomes more complex. Response modulation becomes the final stage (after emotion appears) so that it is more difficult to regulate. The appearance of situations faced by the subject like during fourth day of intervention and third day of the follow up needs the ability to response modulation. Response modulation is a way to regulate emotion by producing alternative adaptive behavior as a response to the emotion being felt. This is a part of response-focused emotion that needs a more complex process and more time (Gross, 2014). However, this can actually be overcome by assistance from surrounding people, like family members and school teachers. The purpose of the assistance here is to help the subject to regulate his emotion as taught.

The decrease of unsuitable behavior generally occurs in school because the subject changes his behavior from unsuitable to become adaptive behavior for emotion regulation as it is taught in the emotion regulation skill system training. Besides that, in school the teacher also helps to remind the subject to show the unsuitable behavior for emotion regulations. Meanwhile, the behavior change at home is not so felt yet because the family members do not remind the subject directly when he shows behavior that is not suitable for emotion regulation. Viewed from the age of the subject, supervision and guidance are still needed by the subject to maintain adaptive behavior for the emotion regulation. This is also in line with the view of the biosocial theory which states that environment also has a role in behavior change.

From the ERC result, the score increase is not significant. ERC questionnaire is chosen because it is a valid and reliable instrument to measure emotion regulation. The non-significant ERC score increase is due to the varied scorers (starting from class teachers, mother, and grandmother of the subject). Their abilities to manage information concerning an item are different from each other. In addition, after further analysis, the questionnaire items are not yet in the form of behavior that can be seen directly and therefore it may cause different meanings to different people.

Meanwhile, from knowledge result, the subject experiences an increase and gets maximum score at the post test, but there is a little decrease during the follow up period since the subject forgets the answer to the questions given. The improvement occurs between the post-test and follow up because the training being given helps the subject to understand abstract concepts by using tools that make them more concrete. The example of abstract concept is the feeling/emotion of the subject. This is made more concrete using emotion flashcards showing emotion expressions pictures, such as happy, sad, and angry, etc. Skills are also made more concrete by using picture cards showing activities representing skills. The training is conducted everyday and homework is given so that the subject is accustomed to reviewing what he has learned. The decrease in the emotion regulation knowledge score during the follow up period is influenced by one deficit in a person with disability, namely in memory ability (Hallahan \& Kauffman, 2006). Hence, 
children with intellectual disability need to be reminded about how to regulate emotion. The more frequent the subject does the emotion regulation, it will eventually become his habit without being instructed.

The result of the skills application in daily life shows that the subject more frequently showed the application of 'getting it right' and 'expressing myself' skills. This may be due to the fact that those skills are the most frequently used in life and are easier to do than problem solving and other skills.

By fulfilling the success indicator requirements, it can be stated that emotion regulation skills system training is effective in developing emotion regulation skills for children with mild intellectual disability. Although the ERC result is not significant, it can be stated that emotion regulation skills system training can increase emotion regulation ability because other criteria that determine the effectiveness of training have been fulfilled. The success in this research is supported by a training system which is adjusted to the limited cognitive capacity of the subject; among other things by making simplification so that the concept being learned can be understood, remembered, and applied more easily, and by using gradual teaching (one by one) to help shape the emotion regulation (Brown, 2016).

The limitation of this research is the different observation ability between the teacher, mother, and grand mother; lack of time to do the intervention because the subject needs to join competition soon; and the small number of participant. The subject for this research is one person only while people in the school environment are also children with intellectual disability who also experience the same problems. Only one person participated because this is a continuation of individual case handling and due to the school bureaucracy of the school and the time given is so short that it is not possible to give training to more than one participant. Therefore, to do another research, the intervention can be done individually with longer time by giving more time for repeating the material not understood yet by the subject. Besides that, further research can be done in the form of group intervention (for instance, students in the same class having the same problem) so that the change does not occur to only one subject but also to others in the environment so that the behavior change is in line with the environment.

This research becomes an additional evidence of the use of emotion regulation skills system because the sources for emotion regulation skills system training are very limited. The implication of this research is that emotion regulation skills system training can be given to a person with intellectual disability in order to help solve problems of emotion regulation. 


\section{REFERENCES}

Berking, M. \& Schwarz, J. (2014). Affect regulation training. In J. J. Gross (Ed.), Handbook of emotion regulation. New York, NY: The Guilford Press.

Black, L., Cullen, C., \& Novaco, R. W. (1997). Anger assessment for people with mild learning disabilities in secure settings. In B. S. Kroese, D. Dagnan, \& K. Loumidis (Ed.), Cognitive-behavior therapy for people with learning disabilities. London: Routledge.

Brown, J. F. (2016). The emotion regulation skills system for cognitively challenged clients: A DBT informed approach. New York, NY: The Guilford Press.

Calkins, S. D., Smith, C. L., Gill, K. L. \& Johnson, M. C. (1998). Maternal interactive styles across contexts: Relations to emotional, behavioral and physiological regulation during toddlerhood. Social Development, 7, 350-369.

Cole, P. M., Dennis, T. A., Smith-Simon, K. E., \& Cohen, L. H. (2009). Preschoolers' emotion regulation strategy understanding: Relations with emotion socialization and child self-regulation. Social Development, 18(2), 324-352.

Cozby, P. C. \& Bates, S. C. (2012). Methods in behavioral research (11th ed.). New York, NY: McGraw-Hill.

Farb, N.A., Anderson, A.K., Irving, J.A., \& Segal, Z.V. (2014). Mindfulness interventions and emotion regulation. In J. J. Gross (Ed.), Handbook of emotion regulation. New York: The Guilford Press.

Glenn, S. \& Cunningham, C. (2002). Self-regulation in children and young people with Down syndrome. In M. Cuskelly, A. Jobling, \& S. Buckley (Ed.), Down syndrome across the life span. London: Whurr Publishers Ltd.

Gravetter, F. J. \& Forzano, L. (2009). Research methods for behavioral sciences (3rd ed.). Belmont, CA: Wadsworth, Cengage Learning.

Gross, J. J. (2014). Handbook of emotion regulation (2nd ed.). New York, NY: The Guilford Press.

Handali, K. A. (2017). Meningkatkan kemampuan regulasi emosi pada anak dengan borderline intellectual functioning tingkat sekolah dasar melalui dialectical behavior therapy (DBT) (Tesis). Depok: Fakultas Psikologi Universitas Indonesia.

Hallahan, D. P. \& Kauffman, J. M. (2006). Exceptional learners: introduction to special education (10th ed.). Boston, MA: Pearson Education Inc.

Kalyuga, S. (2011). Cognitive Load Theory: How many types of load does it really need? Educational Psychology Review, 23(1), 1-19. 
Kumar, R. (2005). Research methodology: A step-by-steep guide for beginners (2nd ed.). London: Sage.

Lew, M., Matta, C., Tripp-Tebo, C., \& Watts, D. (2006). Dialectical behavior therapy (DBT) for individuals with intelectual disabilities: A program descriprion. Mental Health Aspects of Developmental Disabilities, 9, 1-13.

Lindsay, W. R., Michie, A. M., Baty, F. J., Smith, A. H. W., \& Miller, S. (1994). The consistency of reports about feelings and emotions from people with intellectual disability. Journal of Intellectual Disability Research, 38, 61- 66

Linehan, M. M. (2015). Rationale for dialectical behavior therapy skills training. New York, NY: The Guilford Press.

MacLeod, C. \& Grafton, B. (2014). Regulation of emotion through modification of attention. In J. J. Gross (Ed.), Handbook of emotion regulation. New York, NY: Guildford Press.

McClure, K.S., Halpern, J., Wolper, P. A., \& Donahue, J. J. (2009). Emotion regulation and intellectual disability. Journal on Developmntal Disabilities, 15(2), 38-44.

Mennin, D. \& Fresco, D. M. (2014). Emotion regulation therapy. In J. J. Gross (Ed.), Handbook of emotion regulation. New York: The Guilford Press.

Mills, H. \& McCarrol, E. (2012). Emotion regulation in early childhood. Texas Child Care Quareterly, 36(1).

Moore, D.G. (2001). Reassessing emotion recognition performance in people with mental retardation: A review. American Journal on Mental Retardation, 106, 481-502.

Njardvik, U., Matson, J. L., \& Cherry, K. E. (1999). A comparison of social skills in adults with autistic disorder, pervasive developmental disorder not otherwise specified, and mental retardation. Journal of Autism and Developmental Disorders, 29(4), 287-295.

Nolen-Hoeksema, S. (1991). Responses to depression and their effects on the duration of depressive episodes. Journal of Abnormal Psychology, 100, 569-582.

Panfile, T.M. \& D.J. Laible. (2012). Attachment security and child's empathy: The mediating role of emotion regulation. Merrill-Palmer Quarterly, 58(1), 1-21.

Paas, F. \& Sweller, J. (2012). An evolutionary upgrade of cognitive load theory: Using the human motor system and collaboration to support the learning of complex cognitive tasks. Educational Psychology Review, 24(1), 27-45.

Rose, J., \& West, C. (1999). Assessment of anger in people with intellectual disabilities. Journal of Applied Research in Intellectual Disabilities, 12(3), 211-224. 
Scanlon, C. L. (2010). Emotion regulation in children: a guide for teachers. Rusia: University of Pittsburgh.

Schatz, J. N., Smith, L. E., Borkowski, J. G., Whitman, T. L., \& Keogh, D. A. 2008. Maltreatment risk, self-regulation, and maladjustment in at-risk children. Child Abuse and Neglect, 32, 972-982.

Shields, A. \& Cicchetti, D. (1997). Emotion regulation among school-age children: The development and validation of a new criterion Q-Sort Scale. Developmental Psychology, 33(6), 906-916. doi: 10.1037//0012-1649.33.6.906

Sovner, R., \& Hurley, A. D. (1986). Four factors affecting the diagnosis of psychiatric disorders in mentally retarded persons. Psychiatric Aspects of Mental Retardation Reviews, 5(9), 45-49

Stack, D. M., Serbin, L. A., Enn.s, L. N., Ruttle, P. L., \& Barrieau, L. (2010). Parental effects on children's emotion regulation over time and across generations. Infants and Young Children, 23, 52-69.

Sweller, J. (1988). Cognitive load during problem solving: Effects on learning. Cognitive Science, 12, 257-285.

Sweller, J. (2010). Element interactivity and intrinsic, extraneous, and germane cognitive load. Educational Psychology Review, 22(2), 123-138.

Taylor, J. L. (2002). A review of the assessment and treatment of anger and aggression in offenders with intellectual disability. Journal of Intellectual Disability Research, 46(Suppl 1), 57-73.

van Gog, T., Paas, F., \& Sweller, J. (2010). Cognitive load theory: Advances in research on worked examples, animations, and cognitive load measurement. Educational Psychology Review, 22(4), 375-378. 